\title{
MENINGKATKAN HASIL BELAJAR SISWA DENGAN MELALUI MEDIA VISUAL PADA PEMBELAJARAN TEMATIK (TEMA 1 SUB TEMA 2) DI KELAS I SD NEGERI O4 KAJAI PARIAMAN
}

\author{
PINDAWATI \\ SD Negeri 04 Kajai Pariaman
}

\begin{abstract}
The low student learning outcomes in Thematic Learning Theme 1, Sub Theme 2 are caused by several factors, including student activities that are lacking in media that does not exist and the lack of source books for students so that it affects the student's involvement in the learning carried out. In this case the researcher as a class conducted a research entitled "Improving Student Learning Outcomes by Using Visual Media in Thematic Learning (Theme 1 Sub Theme 2) in class I SD Negeri 04 Kaja Pariaman" with the formulation of the problem, namely "Can Visual Media Improve the results? Student Learning in Thematic Learning (Theme 1 Sub Theme 2) in Class I SD Negeri 04 Kaja "The purpose of this study is to improve student learning outcomes in learning theme 1 sub theme 2 in class I SD Negeri 04 Kaja." This research was conducted at SD Negeri 04 Kaja in grade I, and was implemented in two cycles. The first cycle consists of two meetings, the second cycle is also held twice. The problems that will be discussed when using this visual media are determined by the teacher as a researcher. After the first cycle using visual media, the results obtained were only at the beginning, namely active students only reached 60\%. At the end of the second cycle, there was a significant increase, student learning activities on thematic (Theme 1 Sub Theme 2) and learning outcomes. This can be seen in the ongoing learning and the results of the initial and final tests whose average score is 63 to 88, increases. Thus the use of visual media is very supportive and good in improving student learning outcomes in Thematic learning (Theme 1 Sub Theme 2).
\end{abstract}

Keywords: Students, Visual Media, Thematic Learning.

Abstrak: Rendahnya hasil belajar siswa pada Pembelajaran Tematik Tema 1 Sub Tema 2 disebabkan oleh beberapa faktor, diantaranya adalah aktifitas siswa yang sangat kurang media yang tidak ada serta buku sumber bagi siswa yang kurang sehingga berpengaruh terhadap keterlibatan siswa itu pada pembelajaran yang dilaksanakan. Dalam hal ini peneliti sebagai kelas mengadakan penelitian yang berjudul " Meningkatkan Hasil Belajar Siswa dengan Melalui Media Visual pada Pembelajaran Tematik (Tema 1 Sub Tema 2) di kelas I SD Negeri 04 Kajai Pariaman " dengan rumusan masalah yaitu " Apakah melalui Media Visual dapat Meningkatkan hasil Belajar Siswa pada Pembelajaran Tematik (Tema 1 Sub Tema 2) di Kelas I SD Negeri 04 Kajai" Tujuan penelitian ini meningkatkan hasil belajar siswa dalam pembelajaran tema 1 sub tema 2 di kelas I SD Negeri 04 Kajai. Penelitian ini dilaksanakan di SD Negeri 04 Kajai pada kelas I, pelaksanaannya sebanyak dua siklus. Siklus pertama terdiri dari dua kali pertemuan, siklus ke dua juga dilaksanakan sebanyak dua kali pertemuan. Permasalahan yang akan dibahas pada saat mempergunakan media visual ini ditentukan oleh guru sebagai peneliti. Setelah dilaksanakan siklus I dengan mempergunakan media visual maka hasil yang diperoleh baru tahap permulaan, yaitu siswa yang aktif baru mencapai $60 \%$. Pada akhir siklus II baru tampak kenaikan yang signifikan, aktifitas belajar siswa pada Tematik (Tema 1 Sub Tema 2) dan hasil belajarnya .Hal ini dapat dilihat pada pembelajaran berlangsung dan hasil tes awal dan tes akhir yang nilai rata- ratanya 63 menjadi 88, EISSN 2657-0289 $\quad$ Lembaga Penelitian dan Penerbitan Hasil Penelitian Ensiklopedia $\quad 55$ 
meningkat.Dengan demikian penggunaan media visual sangat menunjang dan bagus dalam peningkatan hasil belajar siswa pada pembelajaran Tematik (Tema 1 Sub Tema 2).

Kata Kunci: Siswa, Media Visual, Pembelajaran Tematik.

\section{A. Pendahuluan}

Pasal 1 ayat (1) Undang-undang Nomor 20 tentang Sistem Pendidikan Nasional pada ketentuan umum menyatakan: "Pendidikan adalah usaha sadar dan terencana untuk mewujudkan suasana belajar dan proses pembelajaran agar peserta didik secara aktif mengembangkan potensi dirinya untuk memiliki kekuatan spritual keagamaan, pengendalian diri kepribadian, kecerdasan, akhlak mulia serta keterampilan yang diperlukan dirinya, masyarakat, bangsa dan Negara.". dalam pasal 4 ayat 4 tentang prinsip penyelenggaraan pendidikan dinyatakan: "Pendidikan diselenggarakan dengan memberi keteladanan, membangun keamanan dan mengembangkan kreativitas peserta didik dalam proses pembelajaran" Sesuai dengan Undang-undang diatas diawali kurikulum tahun 1975, kurikulum 1984, kurikulum 2004 (Kurikulum Berbasis Kompetensi), kurikulum 2006 , dan Kurikulum 2013, siswa harus aktif dan kreatif dan guru dituntut memotivasi siswa dalam belajar. Untuk melaksanakan hal diatas memicu lahirnya model-model pembelajaran dan media yang sesuai dengan materi pembelajaran, sehingga ilmu tersebut bisa di transfer ke siswa dan mencapai hasil belajar siswa yang maksimal.

Sebagai pendidik, yang berpijak dengan "paradigma baru yang menyatakan bahwa guru adalah sebagai fasilitator, mediator dan administrator". Dengan demikian siswa dapat diberdayakan untuk memperoleh ilmu pengetahuan dari lingkungan dan memberi kemampuan menguasai tehnik membelajarkan diri secara independent. Media pembelajaran dapat diartikan sebagai suatu kerangka konseptual yang melukiskan prosedur atau langkah yang sistimatis dalam mengelola pengalaman belajar sehingga para siswa dapat mencapai kompetensi tertentu (Soekanto, 1977). Media pembelajaran merupakan pedoman bagi guru dalam menjelaskan dan melaksanakan kegiatan pembelajaran, sehingga kegiatan pembelajaran menjadi kegiatan yang terencana secara sistimatis.

Pada kenyataannya dalam pembelajaran, guru sebagian besar yang aktif dan siswa cenderung pasif. Kurangnya aktivitas siswa tersebut dalam pembelajaran disebabkan oleh beberapa hal antara lain :1) kurangnya buku sumber yang dimiliki oleh siswa, 2) suasana belajar yang tidak menyenangkan bagi siswa, 3) materi yang kurang menarik, 4) sikap guru yang kurang baik, 5) media guru yang yang tidak ada, 6) guru yang kurang menguasai bahan /materi pembelajaran, 7) minat siswa untuk belajar yang kurang. Dilihat dari penyebab di atas pada pembelajaran di SD kelas 1, diharapkan semuanya mampu beraktivitas, dan mengerti apa yang dijelaskan oleh guru, dan yang mungkin cocok dalam proses pembelajaran salah satunya adalah teknik pembelajaran melalui Visual (penayangan gambar dengan LCD Projector) dengan memanfaatkan alat yang ada di SD Negeri 04 Kajai Pariaman.

Dengan demikian guru sebagai peneliti ingin mencoba pembaharuan cara mengajar, yaitu dengan tehnik visual. Oleh karena itu judul penelitian ini adalah " Meningkatkan Hasil Belajar Siswa dengan Melalui Media Visual pada Pembelajaran Tematik (Tema 1 Sub Tema 2) di kelas I SD Negeri 04 Kajai Pariaman”. Berdasarkan latar belakang dan judul penelitian yang dijelaskan diatas maka rumusan masalah adalah : Apakah dengan menggunakan media visual dapat meningkatkan hasil belajar 
siswa kelas I SD Negeri 04 Kajai? Tujuan penelitian ini adalah untuk mendeskripsikan dan mendeskripsikan hasil belajar siswa melalui Media visual dalam pembelajaran sub tema 2 pada kelas I SD N 04 Kajai.

\section{B. Metodologi Penelitian}

Penelitian tindakan ini dilaksanakan di SD Negeri 04 Kajai Pariaman Kelas I yang beralamat Desa Kajai Kecamatan Pariaman Timur Kota Pariaman. Penelitian dilaksanakan pada semester ganjil tahun pelajaran 2019/2020 yakni pada bulan Juli sampai dengan bulan September tahun 2019. Subjek dalam penelitian ini adalah siswa kelas I SD Negeri 04 Kajai tahun pelajaran 2019-2020 semester ganjil yang berjumlah 10 siswa terdiri dari 5 siswa laki-laki dan 5 siswa perempuan. Metode yang digunakan dalam penelitian ini adalah Penelitian Tindakan Kelas (PTK) atau Classroom Action Research yang bertujuan untuk memperbaiki efektifitas dan efisiensi proses pembelajaran. Penelitian Tindakan Kelas merupakan strategi pemecahan masalah yang berfungsi untuk mengambil tindakan yang tepat dalam rangka memperbaiki pembelajaran di kelas. Dalam penelitian ini ada dua tindakan yang diambil yaitu aktifitas tindakan dan aktifitas penelitian. Tindakan ini dilakukan kepada orang yang sama dan bekerja sama dengan kolaborator. Pelaksanaan tindakan dalam penelitian ini meliputi (1) rencana tindakan, (2) pelaksanaan, (3) observasi dan (4) refleksi. Dalam penelitian ini peneliti memulai dari refleksi awal dan penjajakan yang digunakan sebagai dasar untuk merumuskan penelitian. Untuk mengetahui keefektifan suatu metode dalam kegiatan pembealajaran perlu diadakan analisa data, pada penelitian ini mengunakan teknik analisis deskriptif kualitatif, yaitu suatu metode penelitian yang bersifat menggambarkan kenyataan atau fakta sesuai dengan data yang diperoleh dengan tujuan untuk mengetahui prestasi siswa juga untuk memperoleh respon siswa terhadap kegiatan pembelajaaran serta aktivitas siswa selama proses pembelajaran.

\section{Hasil dan Pembahasan}

\section{Siklus I}

Penelitian Tindakan Kelas ini dilaksanakan di kelas I SD Negeri 04 Kajai Pariman. Penelitian tindakan kelas dilakukan selama 2 bulan yang dimulai dari bulan Agustus sampai dengan September tahun 2019. Subyek penelitian berjumlah 10 orang terdiri dari 5 orang siswa putra dan 5 orang siswa putri. Sebelum dilakukan tindakan kelas, terlebih dahulu peneliti menganalisa penyebab-penyebab apa saja yang menyebabkan rendahnya nilai rata-rata hasil belajar kelas I SD Negeri 04 Kajai. Adapun metoda yang digunakan peneliti sebelum tindakan adalah model pembelajaran teacher center approach dengan metoda ceramah. Sehingga siswa hanya mendengarkan apa yang dijelaskan oleh guru, dan takut untuk bertanya.

Dari hasil observasi selama siklus I didapatkan data kemampuan siswa dalam proses pembelajaran sub tema 2 gemar bernyanyi dan menari, siswa masih belum begitu memahami tentang yang ditayangkan. Pada pertemuan kedua siswa sudah agak mengerti tentang isi gambar yang ditayangkan guru. Hasil aktivitas siwa pada siklus I adalah :

Tabel 1 Rekap Aktivitas Siklus I

\begin{tabular}{|c|l|c|c|}
\hline No & \multicolumn{1}{|c|}{ Komponen yang diamati } & Jumlah & Prosentase \\
\hline 1 & Memperhatikan Gambar & 10 & $100 \%$ \\
\hline 2 & Mampu menjelaskan isi gambar & 4 & $40 \%$ \\
\hline 3 & Betanya & 4 & $40 \%$ \\
\hline
\end{tabular}




\begin{tabular}{l|l|c|c}
4 & Rerata & 6 & $60 \%$
\end{tabular}

Berdasarkan data tersebut, ternyata pada siklus I menunjukkan bahwa siswa belum begitu aktif dan guru selalu memberikan respon positif dalam setiap pembelajaran yang dikembangkan dalam penelitian ini. Dilihat dari kemampuan guru memberikan motivasi sangat bagus, tapi karena siswa belum biasa menggunakan media gambar. Pada akhir siklus diadakan tes. Lihat tabel dibawah ini

Tabel 2 Rekap Hasil Belajar pada Siklus I

\begin{tabular}{|c|c|c|c|}
\hline No & Indikator & Jumlah & $\%$ \\
\hline 1 & KKM & 70 & 70 \\
\hline 2 & Rerata & 63 & 63 \\
\hline 3 & Tuntas & 4 & 40 \\
\hline 4 & Tidak Tuntas & 6 & 60 \\
\hline 5 & Daya Serap & 63 & 63 \\
\hline
\end{tabular}

Dari tabel diatas nilai rata-rata pembelajaran sub tema 2 pada siklus I ini adalah nilai rerata 63 dengan ketuntasan belajarnya $63 \%$. Hal ini terjadi ada 6 siswa yang tidak tuntas. Hasil penelitian dari siklus I belum mencapai apa yang dinginkan maka dilanjutkan ke siklus II. Sebelum melanjutkan pada siklus II maka guru melaksanakan tindakan berupa memberikan tugas pada siswa untuk memperhatikan dan mengamati gambar yang akan di tayangkan pada pertemuan berikut dengan catatan harus membaca materi sesuai dengan gambar yang ditayangkan. Dengan demikian siswa sebelum membahas materi punya bahan yang kan di sajikan pada pertemuan berikut, sehingga apa yang akan kita harapkan tercapai hendaknya.

\section{Siklus II}

Hasil peneliti pada siklus II sangat bagus, dan siswa kelas I yang biasanya diam sekarang sudah beranidan mampu untuk mengeluarkan pendapatnya. Hal ini terjadi karena peneliti sebagai guru kelas selalu memberikan bimbingan dan motivasi serta sangat memperhatikan tindakan mereka. Kalau siswa berbuat tidak sesuai dengan peraturan sekolah maka guru sebagai peneliti memberikan nasehat dan membimbingnya dengan baik, sehingga apa yang dinginkan oleh guru tercapai

Hasil aktivitas siswa pada siklus II dapat dilihat pada tabel dibawah ini Tabel 3 Rekap Aktivitas Siklus II

\begin{tabular}{|c|l|c|c|}
\hline No & \multicolumn{1}{|c|}{ Komponen yang diamati } & Jumlah & Prosentase \\
\hline 1 & Memperhatikan Gambar & 10 & $100 \%$ \\
\hline 2 & Mampu menjelaskan isi gambar & 9 & $90 \%$ \\
\hline 3 & Betanya & 8 & $80 \%$ \\
\hline 4 & Rerata & 9 & $90 \%$ \\
\hline
\end{tabular}

Tabel diatas menunjukan hasil aktivitas yang dilaksanakan pada siklus 2, sudah meningkat sehingga di peroleh rerata aktivitas sebesar 90\%,sedangka pada siklus I hanya mencapai $60 \%$, naik $30 \%$. Berdasarkan data tersebut, ternyata pada siklus II menunjukkan bahwa banyak perubahan yang terdapat pada siswa, sehingga apa yang dinginkan tercapai. Pada akhir siklus diadakan tes, untuk hasil tes lihat pada tabeldibawah ini

Tabel: 4 Rekap Hasil Belajar Siklus II

\begin{tabular}{|c|c|c|c|}
\hline No & Indikator & Jumlah & $\%$ \\
\hline 1 & KKM & 70 & 70 \\
\hline 2 & Rerata & 88 & 88 \\
\hline
\end{tabular}




\begin{tabular}{|c|c|c|c|}
\hline 3 & Tuntas & 9 & 90 \\
\hline 4 & Tidak Tuntas & 1 & 10 \\
\hline 5 & Daya Serap & 88 & 88 \\
\hline
\end{tabular}

Dari hasil belajar siklus II sangat bagus sekali rerata hasilnya mencapai 88dengan tingkat ketuntasan 90\% dan yang tidak tuntas hanya 1 Orang (10\%).

\section{Pembahasan}

Penelitian Tindakan Kelas (PTK) pada Pembelajaran Teamatik dengan sub tema 2 materi gemar bernyanyi dan menari di kelas I SD Negeri 04 Kajai Pariaman dengan permasalahan "Upaya peningkatan hasil belajar siswa melalui media visual" ini dilakukan dalam dua siklus. Dampak dari pemakaian media visual pada pembelajaran sub tema 2 materi gemar bernyanyi dan menari sangat baik. Hal ini dapat dilihat dari hasil pengamatan setiap siklus, adanya peningkatan aktivitas siswa dalam proses pembelajaran, karena media visual merupakan media yang dapat menambah keinginan siswa untuk beraktivitas, kreativitas, dengan sendirinya bisa membantu siswa untuk terampil dalam berkomunikasi dan bertanggung jawab untuk mengerjakan tugas, sehingga mampu meningkatkan hasil belajar. Pada Siklus II, kondisi tersebut tampak mengalami perbaikan, mengalami peningkatan yang cukup memuaskan jika dibandingkan dengan kondisinya pada Siklus I seperti terlihat pada tabel berikut:

Tabel 5 Perbandingan aktivitas siklus I dan siklus II

\begin{tabular}{|l|l|c|c|c|c|}
\hline \multirow{2}{*}{ No } & \multirow{2}{*}{ Komponen yang diamati } & \multicolumn{2}{|l|}{ Siklus I } & \multicolumn{2}{l|}{ Siklus II } \\
\cline { 3 - 6 } & & Jml & Prosentase & Jml & Prosentase \\
\hline 1 & Memperhatikan Gambar & 10 & $100 \%$ & 10 & $100 \%$ \\
\hline 2 & Mampu menjelaskan isi gambar & 4 & $40 \%$ & 9 & $90 \%$ \\
\hline 3 & Betanya & 4 & $40 \%$ & 8 & $80 \%$ \\
\hline 4 & Rerata & 6 & $60 \%$ & 9 & $90 \%$ \\
\hline
\end{tabular}

Dari tabel 5 di atas dapat dijelaskan bahwa terjadi peningkatan terhadap aktivitas siswa. Tapi yang memperhatikan atau mengamati gambar dari siklus I sudah $100 \%$,karena mereka tertarik pada gambar tersebut. Yang mampu menjelaskan memang pada siklus I hanya 4 orang dan naik menjadi 9 orang. Adapun hasil belajar yang diperoleh siswa selama siklus I dan siklus II dapat di buat rekapitulasi perbandingannya sebagai berikut:

Tabel 6 Perbandingan Hasil Test siklus I dan siklus II

\begin{tabular}{|c|l|c|c|}
\hline \multirow{2}{*}{ No } & \multirow{2}{*}{ Kriteria } & \multicolumn{2}{|c|}{ Keterangan } \\
\cline { 3 - 4 } & & Siklus I & Siklus II \\
\hline 1. & KKM & 70 & 70 \\
\hline 2. & Rerata & 63 & 88 \\
\hline 3. & Tuntas & 40 & 90 \\
\hline 4. & Tidak Tuntas & 60 & 10 \\
\hline 5. & Daya Serap & 63 & 88 \\
\hline
\end{tabular}

Dari tabel 6 rata-rata nilai siswa pada siklus I ke diklus II mengalami kenaikan 25 point yaitu dari 63 pada siklus I dan 88 pada siklus II. Kenaikan nilai siswa sangat dipengaruhi oleh penguasaan materi.dan penguasaan materi akan terjadi jika pembelajaran di kelas berhasil. Dengan dibantu media visual sangat membantu pemahaman materi dibandingkan dengan teori saja. Model pembelajaran media visual yang ini ternyata dapat menciptakan suasana belajar yang baik dan memotivasi siswa serta memancing kreativitas siswa dalam belajar. 


\section{Penutup}

Sebagai salah satu upaya untuk meningkatkan hasil belajar sub tema 2 siswa di SD Negeri 04 Kajai Pariaman, penggunaan model pembelajaran media visual adalah sangat tepat. Hal ini dapat dilihat dari peningkatan hasil belajar dan perubahan perilaku siswa ketika melaksanakan kegiatan pembelajaran, siswa juga lebih aktif, mereka berani memberikan pendapatnya sehingga proses pembelajaran lebih komunikatif. Dari hasil pembahasan yang sudah diuraikan dalam bab IV sebelumnya, maka peneliti dapat menarik kesimpulan bahwa penggunaan media visual dapat meningkatkan hasil belajar sub tema 2 siswa di SD Negeri 04 Kajai dengan data sebagai berikut: Pada siklus I nilai rata-rata hasil belajar geografi adalah 63, dengan ketuntasan belajar $40 \%$. Pada siklus ke II nilai rata-rata hasil belajar geografi adalah 88 dengan ketuntasan belajar 90 berarti mengalami kenaikan sekitar 25 poin untuk rerata dan $27 \%$ untuk ketuntasan. Selain hasil belajar, aspek keaktifan siswa dalam kegiatan pembelajaran juga mengalami prosentase kenaikan angka dari siklus I dibandingkan siklus II, seperti sikap antusias dalam belajar dan keberanian dalam bertanya. Sehingga menggunakan media visual ini dapat digunakan dalam pembelajaran berikutnya. Dalam meningkatkan hasil belajar geografi, guru perlu mengembangkan diri dan mencari atau memilih model pembelajaran yang tepat untuk materi yang akan diajarkan, Kreatifitas dan inovasi guru sangat diperlukan dalam meningkatkan hasil belajar siswa. Pembelajaran dengan menggunakan metodemedia visual, dapat diterapkan pada mata pelajaran geografi dan pokok bahasan lain, sehingga sangat baik jika dikombinasikan dengan metoda lainnya agar pembelajaran lebih mudah dipahami siswa, menarik dan menyenangkan bagi siswa.

\section{Daftar Pustaka}

Ariani. (1992). Metodologi Penelitian Tindakan Kelas. Padang: FIP UNP

Fajar Arnie, 2003, Forto Folio Dalam Pembelajaran IPS , PT. Remaja Rosda Karya, Bandung.

Hamalik, Umar, 1986, Media Pendidikan, Alumni, Bandung.

Kumpulan Permendiknas tentang Standar Nasional Pendidikan (SNP) 2006, Jakarta

Nana Sudjana, Ahmad Riva'i. (1997). Media Pengajaran. Bandung: CV Sinar Bandung

Undang - Undang No. 20 tentang Sistem Pendidikan Nasional

Sanjaya, Wina,2006, Strategi Pembelajaran, Kencana Prenada Media Group, Jakarta

Suhardjono, Supardi,2009, Strategi menyusun Penelitian Tindakan Kelas, Andi, Semarang.

Sanaky, Media Pembelajaran, (Yogyakarta: Safiria Insania Press, 2009). 